linked immunosorbent assay (ELISA), competitive radioimmunoassay (RIA), complement fixation, and indirect immunofluorescence assays (IFA). J Med Virol 1984;13:361-370.

39. LaRussa P, Steinberg S, Waithe E, Hanna B, Holzman R. Comparison of five assays for antibody to varicella-zoster virus and the fluorescent-antibody-to-membrane-antigen test. J Clin Microbiol 1987;25:2059-2062.

40. Martins TB, Jaskowski TD, Schroder C, Streeter B, Hill HR. Comparison of three commercially available assays for detection of varicella-zoster virus antibody. Clin Diagn Lab Immunol 1994;1:186-188.

41. Weibel RE, Neff BJ, Kuter BJ, et al. Live attenuated varicella virus vaccine. Efficacy trial in healthy children. $N$ Engl J Med 1984;310:1409-1415.

42. Tsolia M, Gershon AA, Steinberg SP, Gelb L. Live attenuated varicella vaccine: evidence that the virus is attenuated and the importance of skin lesions in transmission of varicella-zoster virus. J Pediatr 1990;116:184-189.

43. Diaz PS, Au D, Smith S, et al. Lack of transmission of the live attenuated varicella vaccine virus to immunocompromised children after immunization of their siblings. Pediatrics 1991;87:166-170.

44. Gershon AA. Varicella vaccine: its past, present, and future. Pediatr Infect Dis J 1995;14:742-744.

\title{
Candida Endocarditis From Contaminated Aortic Valve
}

\section{Gina Pugliese, RN, MS Martin S. Favero, $\mathrm{PhD}$}

Fungal endocarditis secondary to extrinsic valve contamination is a rare, but potentially fatal, complication of allograft valve replacement. Its incidence is approximately $0.3 \%$. Treatment is often unsuccessful, and death is a frequent outcome.

The CDC investigated a case of Candida albicans endocarditis associated with a contaminated aortic valve allograft. The findings of this investigation indicated that the antimicrobial processing of the initial aortic valve allograft did not eliminate $C$ albicans from the tissue. The patient had received an aortic valve allograft for aortic insufficiency and, 11 days postoperatively, developed fungal endocarditis with blood cultures positive for $C$ albicans. DNA fingerprinting of the isolate from the valve trimmings during processing and from the recipient were highly similar.

The patient had his valve replaced and received a total of 57 days of therapy with amphotericin B. One year following his valve replacement, he remained free of symptoms. An allograft heart valve is harvested from a brain-dead or postmortem donor not related to the recipient.
Preparation for storage includes incubation in an antimicrobial disinfection solution and cryopreservation. Tissue samples for sterility are obtained by trimming the heart valve when harvested. The trimmings are submitted for bacterial, fungal, and acid-fast culture before antimicrobial disinfection and after cryopreservation. Several different combinations of antifungal agents have been used for antimicrobial disinfection protocols over the years to reduce contamination rates that range from $1.7 \%$ to $28 \%$. However, antifungal agents may damage allograft valve tissue and may be ineffective. Some studies have indicated an equal incidence of fungal contamination after disinfection protocols that include antifungal agents compared to those that do not include antifungal agents. Some tissue banks have removed antifungal agents from the disinfection protocol because of these concerns.

FDA regulations do not require companies processing heart valve allografts to specify the details of the disinfection process (eg, type of antimicrobials used, temperature, duration, sterility testing, or the culture findings that routinely prompt processors to discard a valve). The American Association of Tissue Banks
(AATB) requires its accredited tissue banks to establish, validate, and document antibiotic regimens and microbial surveillance methods.

These accredited organizations employ a similar disinfectant protocol. Five of the six tissue banks that supply most of the heart valve allografts in the United States are nonprofit and accredited by AATB. The sixth tissue bank, Cryolife (Kennesaw, GA), the source of the contaminated valve in this case, is a commercial supplier and not accredited by AATB. Under a recent 1997 proposal published by the FDA for regulation of cellular and tissuebased products, a human heart valve allograft would be subject to donor screening and testing, processing, labeling, and registration requirements. Additional measures that could be considered by the tissue banking community include standardization and validation of the disinfection methods and identification of culture results that indicate allografts must be discarded.

FROM: Centers for Disease Control and Prevention. Candida albicans endocarditis associated with a contaminated aortic valve allograft-California, 1996. MMWR 1997;46:261-263. 